\title{
MENUMBUHKAN KARAKTER KONSERVASI BIODIVERSITAS MELALUI PENERAPAN SPECIES IDENTIFICATION AND RESPONSE SOFTWARE
}

\author{
Mike Dewi Kurniasih \\ IKIP Veteran Jawa Tengah \\ e-mail: kurniasihmike@gmail.com
}

\begin{abstract}
Abstrak
Tujuan penelitian ini adalah untuk mengetahui pengaruh penggunaan aplikasi Species Identification and Response Software (SIRS) pada Mata Kuliah Konservasi Keanekaragaman hayati dalam menumbuhkan karakter konservasi pada diri mahasiswa. Penelitian ini merupakan penelitian tindakan kelas (action research) dengan langkahlangkah penelitian yang meliputi tahap perencanaan, tindakan, observasi, dan refleksi.Penerapan pembelajaran mata kuliah Konservasi Keanekaragaman Hayati berbasis aplikasi SIRS terbukti mampu meningkatkan nilai-nilai karakter konservasi biodiversitas yang meliputi awareness, knowledge, attitudes, skills dan participation. Kenaikan terbesar terjadi pada participation (50\%), pada aspek knowledge terjadi peningkatan sebesar $6.3 \%$. Pada indikator attitude terjadi kenaikan sebesar $12.5 \%$. Indikator skill berada di urutan paling bawah dalam peningkatan masing-masing indikator karakter yang tidak menunjukkan adanya kenaikan yang berarti.
\end{abstract}

Kata Kunci: karakter, konservasi biodiversitas, SIRS

\begin{abstract}
The purpose of this study was to determine whether the use of SIRS (Species Identification and Response Software) applications in Biodiversity Conservation Courses can foster the students' character of conservation. The research hypothesized that the use of SIRS application in Biodiversity Conservation Courses will improve the students' biodiversity conservation characters. The improvement on biodiversity character was assessed from the indicator scores of biodiversity characters. The preliminary study on 100 students of IKIP veteran Jawa Tengah showed that the students' contribution to biodiversity conservation only reached the score of $78.75 \%$. Besides, most students still hesitated to participate in animal trade monitoring for security reason and lack of knowledge. The application of the Biodiversity Conservation subject course based on the SIRS application has been proved to be able to improve the character values of biodiversity conservation which includes awareness, knowledge, attitudes, skills and participation. The biggest improvement occurred in participation $(50 \%)$, in the aspect of knowledge there was an improvement of $6.3 \%$ while in attitude indicator there was an improvement of $12.5 \%$. the indicator of skill were at the bottom of each character indicator with insignificant improvement.
\end{abstract}

Keywords: character, biodiversity conservation, SIRS

\section{PENDAHULUAN}

Keaekaragaman hayati atau yang dikenal dengan sebutan biodiversitas menurut World Wildlife Fund dalam Indrawan (2012) adalah jutaan tumbuhan, hewan dan 
mikroorganisme, serta ekosistem yeng membentuk suatu yang disebut dengan lingkungan hidup. Biodiversitas merupakan kekayaan hidup yang ada di bumi yang meliputi jutaan jenis tumbuhan, hewan, dan mikroorganisme, gen-gen yang dikandungnya, dan ekosistem tempat mereka hidup. Keanekaragaman hayati tersebut sangat penting bagi manusia karena merupakan sumber daya alam yang memiliki nilai ekonomis dan ekologis yang penting. Keanekaragaman spesies dalam ekosistem hutan menghasilkan berbagai macam flora dan fauna yang dapat dimanfaatkan sebagai sumber pangan, tempat tinggal, obatobatan dan kebutuhan hidup yang lain (Indrawan, 2012).

Indonesia merupakan salah satu pusat biodiversitas di bumi yang dikenal sebagai negara mega-biodiversitas. Menurut Supriatna (2008), Indonesia menempati papan atas dalam hal keanekaragaman hayati, yaitu urutan kedua dunia untuk mamalia, pertama dunia untuk tumbuhan palmae, kelima dunia untuk burung, keempat dunia untuk reptil, keenam untuk amfibi, keempat dunia untuk dunia tumbuhan, ketiga dunia untuk ikan air tawar setelah Brazil dan Columbia.

Indonesia sebagai negara mega-biodiversity juga merupakan salah satu negara dengan laju kepunahan spesies terbesar. Penyebabnya antara lain adalah kerusakan hutan, perburuan dan perdagangan satwa langka di pasar gelap. Ketidaktahuan dan ketidakpedulian menyebabkan lemahnya kontrol masyarakat yang memperparah kondisi tersebut. Ironisnya pada saat ini sebagian besar masyarakat sudah tidak memperdulikan lagi manfaat fundamental dari biodiversitas untuk hidupnya, demi masa lalu, sekarang dan masa depan budaya dan ekonomi (Krutschinna \& Streit, 2009).

Pendidikan konservasi merupakan salah satu upaya dalam mengatasi permasalahan tersebut. Konservasi Keanekaragaman Hayati merupakan salah satu mata kuliah yang wajib ditempuh oleh mahasiswa Prodi Pendidikan IPA IKIP Veteran Jawa Tengah. Salah satu tujuan mata kuliah ini adalah menumbuhkan karakter peduli terhadap kekayaan keanekaragaman hayati yang ada.

Permasalahan yang dihadapi dalam perkuliahan konservasi keanekaragaman hayati selama ini masih berbasis buku teks, belum sepenuhnya kontekstual, hanya sebatas mentranser informasi sehingga mahasiswa cenderung apatis dan belum mampu memunculkan karakter konservasi sebagai salah satu tujuan perkuliahan. Hal serupa juga dikemukakan oleh Desfandi (2015) bahwa materi dan metode yang diterapkan dalam proses pendidikan lingkungan hidup dirasakan belum cukup, dan kurang aplikatif, sehingga pemahaman yang didapat mengenai pelestariannya menjadi tidak utuh.

Berdasarkan masalah-masalah tersebut perlu suatu model pembelajaran dimana mahasiswa dapat lebih aktif dalam kegiatan konservasi misalnya dengan ikut melakukan scan, identify and response terhadap flora atau fauna yang dilindungi yang ada atau diperjual belikan di sekitar mereka. Kegiatan tersebut diharapkan akan melatih mahasiswa 
dalam mengidentifikasi flora dan fauna yang dilindungi oleh pemerintah, membagikan informasi tentang temuannya dan mengambil tindakan yang tepat mengenai hal tersebut dengan menggunakan perangkat SIRS. Penggunaan aplikasi SIRS sangat sirankan untuk diterapkan di dalam pembelajran mata kuliah konservasi karena mampu meningkatkan karakter konservasi yaitu meliputi aspek knowledge, awareness, attitude dan participation. Hasil penerapan perangkat SIRS dalam mata kuliah Konservasi Keanekaragaman Hayati diharapkan dapat menumbuhkan karakter konservasi serta mewujudkan perkuliahan yang kontekstual dan bermakna.

\section{METODE}

Penelitian ini merupakan penelitian tindakan kelas (PTK). PTK sebagai suatu penelitian bersifat reflektif melalui tindakan-tindakan tertentu dengan tujuan untuk memperbaiki dan meningkatkan proses pembelajaran di kelas secara profesional. Lokasi Penelitian adalah di IKIP Veteran Jawa Tengah. Subjek penelitian ini adalah mahasiswa pendidikan IPA Semester 5 tahun ajaran 2017/2018. Menurut model Kemmis dan Mc Taggart dalam Arikunto (2006), langkah-langkah PTK terdiri atas tahap perencanaan, tindakan, observasi, dan refleksi.

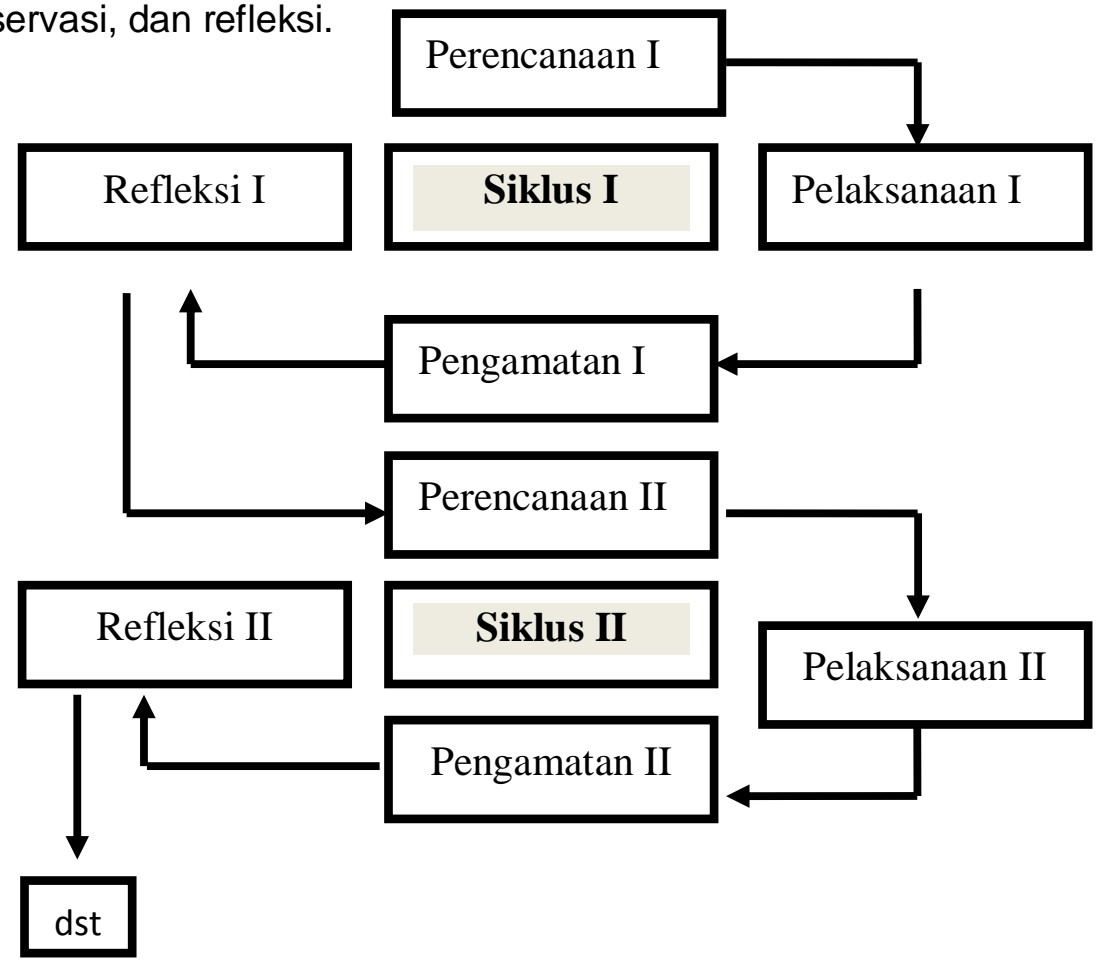

Gambar 1. Desain Penelitian Tindakan menurut Kemmis dan Taggart

Data yang dikumpulkan dalam penelitian ini adalah sebagai berikut 1) Data hasil tes hasil belajar mata kuliah Konservasi Biodiversitas 2) Data hasil observasi ekspresi karakter konservasi biodiversitas dan 3) Angket untuk mengetahui respon mahasiswa terhadap konservasi biodiversitas. Teknik yang digunakan dalam mengumpulkan data 
adalah tes, observasi, angket dan dokumentasi. Data yang didapatkan dianalisis secara deskriptif kuantitatif.

Indikator keberhasilan dalam penelitian ini adalah setelah dilakukan tindakan maka terjadi peningkatan karakter kepedulian dan partisipasi mahasiswa dalam hal konservasi biodiversitas yang nampak dari observasi ekspresi karakter konservasi biodiversitas dan keaktifannya dalam menggunakan aplikasi SIRS dalam perkuliahan. Karakter peduli biodiversitas dan indikatornya dapat dilihat pada Tabel 1.

Tabel 1. Karakter Peduli Biodiversitas \& Indikatornya

\begin{tabular}{|c|c|c|c|}
\hline No & $\begin{array}{c}\text { Karakter } \\
\text { Konservasi } \\
\text { Biodiversitas }\end{array}$ & Indikator & Model Pembelajaran \\
\hline \multirow[t]{4}{*}{1.} & \multirow[t]{4}{*}{$\begin{array}{l}\text { Knowledge } \\
\text { (Pengetahuan) }\end{array}$} & $\begin{array}{l}\text { Mahasiswa mengetahui } \\
\text { keanekaragaman hayati di } \\
\text { Indonesia }\end{array}$ & $\begin{array}{l}\text { Diskusi aktif dan Kunjungan } \\
\text { Lapangan }\end{array}$ \\
\hline & & $\begin{array}{l}\text { Mahasiswa mengetahui spesies } \\
\text { flora dan fauna yang dilindungi di } \\
\text { Indonesia }\end{array}$ & $\begin{array}{l}\text { Diskusi aktif dan Kunjungan } \\
\text { Lapangan }\end{array}$ \\
\hline & & $\begin{array}{l}\text { Mahasiswa mengetahui status } \\
\text { konservasi suatu spesies } \\
\text { berdasarkan kriteria IUCN }\end{array}$ & $\begin{array}{l}\text { Diskusi aktif dan Kunjungan } \\
\text { Lapangan }\end{array}$ \\
\hline & & $\begin{array}{l}\text { Mahasiswa mampu menjelaskan } \\
\text { tata cara identifikasi spesies }\end{array}$ & $\begin{array}{l}\text { Ceramah dikombinasikan } \\
\text { dengan penggunaan } \\
\text { aplikasi SIRS }\end{array}$ \\
\hline 2. & $\begin{array}{l}\text { Awareness } \\
\text { (Kepedulian) }\end{array}$ & $\begin{array}{l}\text { Mahasiswa menyadari pentingnya } \\
\text { pelestarian keanekaragaman } \\
\text { hayati }\end{array}$ & $\begin{array}{l}\text { Diskusi dan kunjungan } \\
\text { lapangan }\end{array}$ \\
\hline \multirow[t]{2}{*}{3.} & \multirow[t]{2}{*}{$\begin{array}{l}\text { Skill } \\
\text { (Keterampilan) }\end{array}$} & $\begin{array}{l}\text { Mahasiswa mampu melakukan } \\
\text { identifikasi spesies flora dan fauna } \\
\text { yang dilindungi }\end{array}$ & $\begin{array}{l}\text { Eksplorasi dan Investigasi } \\
\text { keberadaan satwa yang } \\
\text { dilindungi dengan aplikasi } \\
\text { SIRS di lapangan }\end{array}$ \\
\hline & & $\begin{array}{l}\text { Mahasiswa mampu menggunakan } \\
\text { aplikasi SIRS untuk melakukan } \\
\text { tindakan yang tepat atas } \\
\text { penemuan organisme langka yang } \\
\text { dipelihara maupun diperjualbelikan. }\end{array}$ & $\begin{array}{l}\text { Penggunaan fitur response } \\
\text { pada aplikasi SIRS apabila } \\
\text { ditemukan terduga satwa } \\
\text { langka di lapangan }\end{array}$ \\
\hline 4. & Attitude (Sikap) & $\begin{array}{l}\text { Mahasiswa menunjukkan sikap } \\
\text { kepedulian terhadap pelestarian } \\
\text { keanekaragaman hayati }\end{array}$ & $\begin{array}{l}\text { Penanaman sikap melalui } \\
\text { budaya conservation } \\
\text { conciousness dalam } \\
\text { suasana akademik di } \\
\text { kampus }\end{array}$ \\
\hline 5. & $\begin{array}{l}\text { Participation } \\
\text { (Partisipasi) }\end{array}$ & $\begin{array}{l}\text { Mahasiswa ikut serta dalam } \\
\text { melaksanakan kontrol konservasi } \\
\text { keanekaragaman hayati }\end{array}$ & $\begin{array}{l}\text { Sharing data dan report } \\
\text { hasil temuan flora/fauna } \\
\text { langka di lapangan }\end{array}$ \\
\hline
\end{tabular}

Indikator karakter konservasi biodiversitas pada Tabel 1 digunakan sebagai acuan dalam pembuatan lembar observasi untuk mengetahui nilai tingkat ketercapaian karakter konservasi biodiversitas. Adapun nilai ketercapaian karakter konservasi biodiversitas dapat dilihat pada Tabel 2. 
Tabel 2. Kriteria Ketercapaian Karakter Biodiversitas

\begin{tabular}{lcc}
\hline No. & Interval (\%) & Kriteria \\
\hline 1. & $86-100$ & Sangat Tinggi \\
\hline 2. & $71-85$ & Tinggi \\
\hline 3. & $56-70$ & Cukup Tinggi \\
\hline 4. & $41-55$ & Rendah \\
\hline 5. & $25-40$ & Sangat Rendah \\
\hline
\end{tabular}

Analisis penilaian karakter konservasi biodiversitas mahasiswa pada tiap indikator diukur berdasarkan skor dari setiap indikator dengan rumus:

$$
\text { Nilai }=\frac{\text { jumlah skor yang diperoleh }}{\text { jumlah skor maksimal }} \times 100 \%
$$

Penerapan SIRS dikatakan berhasil menumbuhkan karakter konservasi biodiversitas apabila minimal $75 \%$ mahasiswa berada pada minimal kriteria ketercapaian karakter biodiversitas kategori cukup tinggi.

\section{HASIL DAN PEMBAHASAN}

\section{Pelaksanaan Siklus 1}

a. Perencanaan Tindakan

Kegiatan yang dilakukan pada tahapan ini adalah menyusun perangkat pembelajaran berupa RPS, silabus, media pembelajaran dan instrumen penilaian. Instrumen penilaian yang dibuat berupa lembar observasi, angket, lembar penugasan dan soal tes uraian. Media pembelajaran yang digunakan berupa presentasi Power Point dan aplikasi SIRS (Species Identification and Response Software) dengan yang dikembangkan oleh Taronga Conservation Society Australia. Aplikasi SIRS sebelum digunakan dicoba digunakan oleh peneliti untuk untuk mengetahui kepraktisan dalam penggunaannya. Instrumen penilaian berupa tes telah melalui uji validitas dan reliabilitas dengan menggunakan program SPSS. Hasil analisis SPSS menunjukkan bahwa soal dalam kategori valid dan reliabel.

Perangkat pembelajaran dan instrumen observasi yang dihasilkan lalu melewati tahap uji validasi oleh ahli. Validator yang dilibatkan dalam penelitian ini adalah ahli evaluasi dan ahli perencanaan pembelajaran. Hasil validasi menunjukkan bahwa perangkat pembelajaran layak untuk diterapkan dengan skor rata-rata 3.25 dalam skala pengukuran 1-4.

Saran dari validator adalah referensi yang digunakan dalam penyusunan bahan ajar diusahakan terbaru. Soal yang digunakan untuk evaluasi ditambah tingkat kesulitannya dan juga ditambah soal yang tergolong ranah C5 dan C6 dalam Taksonomi Bloom. Saran lainnya adalah perlunya perencanaan yang lebih hati-hati terkait dengan 
kegiatan observasi lapangan untuk pengamatan perdagangan satwa liar dilindungi karena terkait aspek keamanan.

Hal tersebut menjadi alasan perubahan rencana awal dimana pengamatan satwa liar yang akan dikunjungi seluruh mahasiswa dan dosen akhirnya diubah dengan menugaskan mahasiswa secara mandiri karena alasan keamanan dan aspek menjaga kerahasiaan proses observasi. Hal tersebut diperlukan untuk menjaga kevalidan data hasil observasi yang didapatkan.

\section{b. Pelaksanaan Tindakan}

Pertemuan pertama siklus I diawali dengan dosen membuka pembelajaran dengan mengucapkan salam, mengecek presensi kehadiran dan menyampaikan capaian pembelajaran yang akan dicapai. Dosen menyampaikan apersepsi dan sebelum memulai pembelajaran, dosen memberikan kesempatan kepada mahasiswa untuk menanyakan halhal yang dianggap sulit. Dosen menyampai materi tentang kriteria kepunahan makhluk hidup menurut IUCN (International Union for Conservation of Nature and Natural Resources) dan CITES (Convention on International Trade in Endangered Species of Wild Fauna and Flora) kemudian dilanjutkan dengan menjelaskan upaya-upaya yang dapat dilakukan untuk dapat menekan laju kepunahan tersebut melalui metode ceramah. Dosen memberikan tugas kepada mahasiswa untuk mendiskusikan tentang upaya kreatif yang bisa dilakukan untuk membantu upaya konservasi biodiversitas secara kelompok. Masingmasing kelompok terdiri atas tiga mahasiswa. Hasil diskusi kemudian dipresentasikan di depan kelas. Dari semua kelompok hanya dua kelompok yang berani menampilkan hasil diskusinya. Kelompok yang lain rata-rata masih malu-malu dan kesulitan dalam menemukan ide kreatif sehingga enggan untuk menampilkannya. Kelompok pertama yang menampilkan hasil diskusinya mengemukakan ide yaitu memberikan penanda bagi semua spesies terancam punah yang hidup di alam dengan menggunakan chip agar dapat terpantau dimanapun keberadaan mereka, ide lain yang muncul adalah memanfaatkan media fashion untuk melakukan kampanye anti perdagangan satwa dengan memasukkan pesan-pesan tentang konservasi pada tulisan-tulisan di produk fashion tersebut. Kelompok kedua yang maju memberikan ide tentang penggunaan aplikasi untuk menghitung dan memetakan keberadaan flora dan fauna di dunia untuk dapat memantau status kelestariannya. Ide yang lain adalah menerapkan kewajiban satu rumah satu pohon untuk mendukung upaya konservasi. Di akhir presentasi dosen memberikan refleksi bagi kelompok-kelompok yang telah menampilkan ide-idenya.

Setelah tahap diskusi, kegiatan selanjutnya adalah penugasan dimana mahasiswa diminta untuk mengunduh aplikasi SIRS. Kemudian dosen meminta mahasiswa untuk mengaplikasikan SIRS dalam lima hari terhitung dari tanggal pemberian tugas. Dosen mejelaskan cara aman dalam penggunaan SIRS serta lokasi-lokasi penting untuk tempat 
mengaplikasikannya. Sebelum mengaplikasikan SIRS mahasiswa diminta untuk mempelajari tentang PP RI no.7 tahun 1999 tentang pengawetan jenis tumbuhan dan satwa yang memuat tentang daftar flora dan fauna yang dilindungi di Indonesia. Setelah mereka mempelajari dokumen tersebut diharapkan mahasiswa dapat mengidentifikasi satwa mana yang ditengarai termasuk ke dalam daftar satwa dilindungi dan mana yang bukan. Hasil observasi dengan menggunakan aplikasi SIRS ini dipresentasikan pada pertemuan selanjutnya. Selama lima hari tersebut mahasiswa dapat bertanya kepada dosen tentang hal-hal yang tidak diketahui. Kriteria penilaian dari kegiatan ini adalah dari segi keaktifan mahasiswa dan hasil pengamatan yang dilakukan.

Kegiatan penutup dilakukan dengan perumusan kesimpulan dan pemberian penguatan terhadap materi yang telah diajarkan. Dalam tahapan ini juga dijelaskan gambaran tentang pembelajaran selanjutnya.

c. Hasil Tindakan

Dapat disimpulkan mahasiswa pada siklus I ini terlihat masih merasa canggung untuk aktif dalam perkuliahan sehingga aspek keterlibatan mahasiswa masih tergolong rendah. Hal tersebut dilihat dari jumlah kelompok yang bersedia mempresentasikan hasil diskusinya di depan kelas. Pada siklus pertama ini juga dijumpai mahasiswa masih enggan untuk menggunakan aplikasi SIRS karena masih merasa ragu terhadap aspek keamanannya. Hasil penugasan observasi dengan aplikasi SIRS didapatkan bahwa mahasiswa rata-rata melaporkan hasil pengamatannya secara langsung tanpa melalui aplikasi SIRS. Mahasiswa menggunakan aplikasi WhatsApp untuk menanyakan kepada dosen tentang satwa yang mereka jumpai dan dokumentasikan. Lokasi yang dijadikan tempat observasi antara lain pasar satwa, toko satwa dan lingkungan sekitar tempat tinggal mahasiswa. Skor hasil pengamatan karakter konservasi biodiversitas dapat dilihat pada tabel 3.

Tabel 3. Karakter Konservasi Biodiversitas Siklus I

\begin{tabular}{llcc}
\hline No & \multicolumn{1}{c}{$\begin{array}{c}\text { Karakter Konservasi } \\
\text { Biodiversitas }\end{array}$} & $\begin{array}{c}\text { Skor Siklus 1 } \\
(\%)\end{array}$ & Kriteria \\
\hline 1. & Knowledge (pengetahuan) & 75.0 & Tinggi \\
\hline 2. & Awareness (kepedulian) & 50.0 & Rendah \\
\hline 3. & Skill (keterampilan) & 62.5 & Cukup tinggi \\
\hline 4. & Attitude (sikap) & 62.5 & Cukup tinggi \\
\hline 5. & Participation (Partisipasi) & 50.0 & Rendah \\
\hline
\end{tabular}

Selain mengamati munculnya indikator karakter bioviversitas, observer juga mengamati aspek keaktifan, kedisiplinan, etika dan kerjasama mahasiswa di dalam pembelajaran. Hasil pengamatan menunjukkan skor keaktifan dan antusiasme sebesar $62,5 \%$, Kedisiplinan sebesar $50 \%$, etika dan kerjasama sebesar $62,5 \%$. 


\section{d. Refleksi dan Evaluasi}

Refleksi pada siklus I dilakukan dengan mengkaji hasil dan permasalahan yang dihadapi. Pada siklus I diperoleh data bahwa mahasiswa antusias dalam pembelajaran tersebut, walaupun belum optimal. Beberapa kelemahan yang ditemukan dalam siklus I adalah mahasiswa belum menunjukkan kreativitasnya secara maksimal. Hal tersebut terjadi karena keterbatasan waktu dalam menuliskan ide-ide mereka. Kurangnya referensi untuk memunculkan ide baru juga diungkapkan mahasiswa dalam wawancara. Hasil analisis dan refleksi siklus I belum menunjukkan belum munculnya indikator konservasi biodiversitas yang secara optimal sehingga perlu dilakukan tindakan Siklus 2.

e. Tindak Lanjut

Untuk meningkatkan pencapaian indikator konservasi biodiversitas maka peneliti merancang solusi untuk memperbaiki kekurangan-kekurangan yang muncul pada siklus I. Dosen mengubah cara pemberian tugas dari dikerjakan langsung selama pembelajaran menjadi take home. Penugasan dalam bentuk take home ini memungkinkan mahasiswa untuk lebih mengeksloprasi ide-ide dan melengkapinya dengan referensi-referensi sehingga menjadi karya tulis yang lebih bermutu.

Penugasan untuk mengaplikasikan SIRS masih belum efektif pada pertemuan pertama. Pada pertemuan kedua dosen memberikan materi tentang list hewan yang dilindungi di Indonesia menurut peraturan perundang-undangan yang berlaku sehingga mahasiswa memperoleh gambaran yang lebih jelas mengenai satwa apa saja yang termasuk di dalam daftar sebelum mahasiswa mengaplikasikan SIRS. Dosen juga perlu memberikan pengarahan yang lebih mendalam tentang tata cara penggunaan aplikasi sehingga mahasiswa tidak ragu dalam menggunakannya.

\section{Pelaksanaan Siklus 2}

\section{a. Perencanaan}

Kegiatan yang dilakukan pada tahapan ini adalah merevisi perangkat pembelajaran berupa RPS, silabus, media pembelajaran dan instrumen penilaian yang telah diterapkan pada siklus I. Revisi dilakukan terutama pada lembar observasi, lembar penugasan mahasiswa, dan RPS.

Persiapan juga dilakukan dengan melakukan briefing sebelum penugasan pertemuan kedua pada siklus kedua. Sehingga mahasiswa tau apa saja yang harus dilakukan di lapangan. Sebelum kegiatan dosen mengecek apakah semua mahasiswa telah mengunduh aplikasi SIRS atau belum. Berdasarkan hasil pengamatan ada dua mahasiswa yang kesulitan mengintal aplikasi karena beberapa alasan. Alasan tersebut adalah HP yang digunakan tidak kompatibel dan alasan lainnya adalah memori HP penuh dan belum dapat terinstal.

b. Pelaksanaan tindakan 
Dosen membuka pelajaran dengan mengucapkan salam, mengecek presensi dan menyampaikan capaian pembelajaran. Dosen menyampaikan apersepsi dan memberikan kesempatan kepada mahasiswa untuk menanyakan hal-hal yang dianggap sulit. Dosen menyampai materi tentang kriteria kepunahan makhluk hidup menurut IUCN dan CITES kemudian dilanjutkan dengan menjelaskan upaya-upaya yang dapat dilakukan untuk dapat menekan laju kepunahan tersebut melalui ceramah. Dosen menjelaskan tentang PP RI no.7 tahun 1999 tentang pengawetan jenis tumbuhan dan satwa yang memuat tentang daftar flora dan fauna yang dilindungi di Indonesia. Setelah mereka mempelajari materi tersebut diharapkan mahasiswa dapat mengidentifikasi satwa mana yang ditengarai termasuk ke dalam daftar satwa dilindungi dan mana yang bukan melalui pemanfaatan aplikasi SIRS.

Dosen memberikan penugasan untuk membuat tulisan tentang ide-ide kreatif tentang upaya yang dapat dilakukan mahasiswa untuk mendukung upaya pemerintah dalam melakukan konservasi keanekaragaman hayati. Laporan tersebut harus dikumpulkan mahasiswa pada pertemuan selanjutnya. Setelah dosen memberikan tugas tersebut, dosen menyampaikan tentang tugas selanjutnya yaitu melakukan pengamatan mandiri dengan menggunakan aplikasi SIRS. Pengamatan dapat dilakukan di sekitar lingkungan tempat tinggak mahasiswa maupun di tempat-tempat lain yang berpotensi menjadi tempat perdagangan satwa maupun produk olahan satwa liar dilindungi di sekitar mereka di pertemuan ke dua pada siklus ke dua.

Hasil pengamatan siklus kedua mahasiswa menunjukkan bahwa meskipun mahasiswa telah melakukan pengamatan di berbagai tempat namun mahasiswa belum menemukan hewan yang masuk dalam daftar dilindungi di lokasi-lokasi tersebut. Satwa yang ditemukan mahasiswa antara lain ayam mutiara, iguana, tokek hias, burung-burung hias yang umum (kepodang, love bird, merpati dll), kelelawar, kura-kura brazil dll yang merupakan spesies hewan tidak dilindungi. Mahasiswa hanya mendapatkan duri landak (Hystrix sp) dan ekor biawak (Varanus sp) yang merupakan bagian dari satwa yang dilindungi tersebut. Meskipun tidak banyak hewan maupun bagian dari hewan yang masuk dalam daftar dilindungi yang diketemukan namun tujuan utama dari penerapan aplikasi SIRS telah tercapai yaitu meningkatkan kepedulian mahasiswa untuk ikut berpartisispasi dalam menjaga kelestarian keanekaragaman hayati telah tercapai.

Kegiatan penutup dilakukan dengan perumusan kesimpulan dan pemberian penguatan terhadap materi yang telah diajarkan. Dalam tahapan ini juga dijelaskan gambaran tentang pembelajaran selanjutnya.

c. Hasil Tindakan

Hasil pengamatan yang dilakukan dibandingkan siklus 1, pada siklus 2 menunjukkan bahwa terjadi peningkatan ketercapaian indikator konservasi biodiversitas. 
Dari hasil penelitian diketahui terjadi peningkatan nilai karakter mahasiswa yang ditunjukkan dengan tabel 4

Tabel 4. Perbandingan Karakter Konservasi Biodiversitas pada Siklus I dan II

\begin{tabular}{llccc}
\hline No & $\begin{array}{c}\text { Karakter Konservasi } \\
\text { Biodiversitas }\end{array}$ & $\begin{array}{c}\text { Skor Siklus I } \\
(\%)\end{array}$ & $\begin{array}{c}\text { Skor Siklus II } \\
(\%)\end{array}$ & $\begin{array}{c}\text { Kenaikan } \\
(\%)\end{array}$ \\
\hline 1. & Knowledge (pengetahuan) & 75.0 & 81.3 & 6.3 \\
\hline 2. & Awareness (kepedulian) & 50.0 & 75.0 & 25.0 \\
\hline 3. & Skill (keterampilan) & 62.5 & 62.5 & 0 \\
\hline 4. & Attitude (sikap) & 62.5 & 75.0 & 12.5 \\
\hline 5. & Participation (Partisipasi) & 50.0 & 100.0 & 50.0 \\
\hline Rata-rata & 60.0 & 78.8 & 18.8 \\
\hline
\end{tabular}

Hasil tersebut menunjukkan bahwa penerapan aplikasi SIRS mampu meningkatkan karakter konservasi biodiversitas pada mahasiswa. Pada siklus II didapatkan nilai karakter konservasi biodiversitas dalam kriteria tinggi.

Pembelajaran Sato (2000) membagi tiga model pendidikan lingkungan yang bermanfaat untuk meningkatkan skill, attitude dan knowledge tentang lingkungan, yaitu melalui kegiatan in/trough the environment, about the environment dan for the environment. Pelibatan mahasiswa dalam kegiatan ini menjadi salah satu faktor penyebab keberhasilan dalam peningkatan karakter konservasi biodiversitas pada penelitian ini. Pada model In/Trough the environment, mahasiswa diajak ke lingkungan untuk mengamati perdagangan satwa liar dilindungi dan melihat kenyataan yang ada, sehingga mendapatkan kesan (feeling) tertentu. Pada tahapan ini mahasiswa mendapatkan suatu pengalaman yang berharga. Model pendidikan about the environment misalnya saat membahas tentang isu-isu konservasi bertujuan untuk memberikan pengertian (understanding) pada mahasiswa agar menjadi peduli (concern). Sedangkan model pendidikan for the environment misalnya dengan melakukan kegiatan yang pro konservasi bertujuan untuk menciptakan perubahan perilaku mahasiswa sehingga dapat melakukan kegiatan (action) yang berhubungan dengan permasalahan dalam konservasi keanekaragaman hayati yang dijumpai.

Hal yang serupa diungkapkan oleh penelitian yang dilakukan oleh Dikmenli (2010) dan Ramados \& Moli (2011) bahwa pembelajaran konservasi biodiversitas yang terbaik adalah dengan menggunakan alam sekitar sebagai sumber belajar. Penggunaan teknologi sebagai alat kontrol terhadap kelestarian biodiversitas juga sangat penting. Melalui ICT masyarakat khususnya dalam hal ini adalah mahasiswa dapat melakukan check and act terhadap keberadaan suatu spesies sehingga mempermudah dalam melakukan monitor baik jumlah maupun sebaran spesies tersebut di alam dan berpartisipasi dalam upaya pelestariannya (Maezawa, Hatakeyama, Saito \& Hirota, 2014). 
Pembelajaran berbasis Scan, Identify and Response dapat meningkatkan karakter konservasi dalam aspek knowledge, awareness, attitude dan participation. Peningkatan dari aspek knowledge dapat terlihat dari peningkatan pengetahuan mahasiswa akan keanekaragaman hayati di Indonesia yang termasuk dalam kategori dilindungi. Peningkatan dalam aspek knowledge juga dapat terlihat dari peningkatakn kemampuan mahasiswa dalam menjelaskan tata cara identifikasi spesies. Peningkatan knowledge terbukti juga mempengaruhi aspek attitude, hal tersebut sesuai dengan pendapat Chen et al (2011) \& Venuste et al (2017) yang mengemukakan bahwa ada hubungan antara pengetahuan dengan sikap. Ketika pengetahuan bertambah maka sikap positif juga akan meningkat.

Peningkatan aspek awareness menunjukkan bahwa mahasiwa menyadari arti penting keanekaragaman hayati. Pembelajaran dengan SIRS berdampak positif terhadap keaktifan mahasiswa dalam pembelajaran mata kuliah konservasi biodiversitas. Mahasiswa lebih aktif bertanya dan mengemukanan pendapat selama pembelajaran setelah adanya penerapan aplikasi SIRS.

Dalam aspek sikap (attitude) menunjukkan adanya peningkatan dalam hal rasa kepedulian terhadap pelestarian keanekaragaman hayati. Hal tersebut terlihat dari jawaban mahasiswa terhadap beberapa pertanyaan tentang konservasi yang meliputi sikap terhadap awetan satwa langka dan kontrubusi terhadap konservasi yang menunjukkan adanya peningkatan.

Aspek participation terlihat dari adanya partisipasi aktif mahasiswa dalam melakukan pemantauan terhadap perdagangan satwa liar dilindungi melalui aplikasi SIRS yang berbasis IT. Hal tersebut sesuai dengan pendapat Tiwari (2010) bahwa penggunaan IT dapat meningkatkan kesempatan bagi individu maupun masyarakat untuk ikut berpartisipasi dalam memcahkan permasalahan dan mengedukasi tentang konservasi biodiversitas. Di dalam konservasi biodiversitas, pengumpulan data yang efisien dan dengan penggunaan informasi yang kompleks dan beragam mampu berkontribusi dalam mencegah dan mengurangi penurunan biodiversitas dan peningkatan dalam hal penggunaan secara berkeanjutan (Maezawa et al, 2014).

\section{SIMPULAN}

Hasil penelitian ini dapat disimpulkan bahwa (1) Penerapan pembelajaran mata kuliah Konservasi Keanekaragaman Hayati berbasis aplikasi SIRS terbukti mampu meningkatkan nilai-nilai karakter konservasi biodiversitas yang meliputi awareness, knowledge, attitudes, skills dan participation. (2) Pengetahuan mahasiswa pada biodiversitas di Indonesia yang termasuk dalam kategori dilindungi dan tata cara identifikasinya menunjukkan peningkatan. (3) Pembelajaran dengan SIRS memberikan 
dampak positif terhadap keaktifan mahasiswa dalam pembelajaran mata kuliah konservasi biodiversitas.

\section{DAFTAR PUSTAKA}

Arikunto. 2006. Prosedur Penelitian Suatu Pendekatan Praktek. Jakarta: PT. Rineka Cipta.

Chen, X., Peterson M.N., Hull V., Lu C., Lee G.D., Hong D \& Liu J. 2011. Effects of Attitudinal and Socio-Demographic Factors on Pro-Environmental Behavior in Urban China. Environmental Conservation, 38 (1), 45-52.

Desfandi, M. 2015. Mewujudkan Masyarakat Berkarakter Peduli Lingkungan melalui Program Adiwiyata. Social Science Education Journal, 2 (1), 31-37.

Dikmenli, M. 2010. Biology Student Teacher's Conceptual Frameworks Regarding Biodiversity. Education, 130 (3), 479-489.

Indrawan, M., Primack, R.B \& Supriatna, J. 2012. Biologi Konvservasi. Jakarta : Yayasan Obor Indonesia.

Krutschinna, J \& Streit, B. 2009. The Biodiversity Network Bio Frankfrut. An Innovative Strategic Approach to Integrative Research, Conservation and Education. Biorisk. 3. 21-25.

Maezawa, Y., Hatakeyama, Y., Saito, M \& Hirot, F. 2014. Fujitsu Science \& Technology Journal. 50 (4), 44-51.

Ramadoss, A \& Moli, G.P. 2011. Biodiversity Conservation Through Environmental Education for Sustainable Development - A Case Study From Puducherry, India. International Electronic Journal of Environmental Education. 1(2), 97-111.

Sato, M. 2000. Teaching Methodology Options for Environmental Education. IGES-JICA Training Materials.

Supriatna, J. 2008. Melestarikan Alam Indonesia. Jakarta: Yayasan Obor Indonesia.

Tiwari, A. 2010. Role of Information Technology (IT) in Biodiversity Conservation. National Conference on Biodiversity, Development dan Poverty Alleviation. 114-116.

Venuste, N., Oliver, H \& Valens, N. 2017. Knowledge, Attitudes and Awareness of Pre Service Teachers on Biodiversity Conservation in Rwanda. International Journal of Environmental \& Science Education. 12 (4), 643-652. 